\title{
New radiocarbon dates and Bayesian models for Nelson Bay Cave and Byneskranskop 1: implications for the South African Later Stone Age sequence
}

Loftus, Emma ${ }^{1 *}$; Sealy, Judith ${ }^{2}$ and Lee-Thorp, Julia ${ }^{1}$

*emma.loftus@rlaha.ox.ac.uk

${ }^{1}$ Research Laboratory for Archaeology, University of Oxford, Dyson Perrins Building, South Parks Road, OX1 3QU, United Kingdom

${ }^{2}$ Department of Archaeology, University of Cape Town, Private Bag X3, Rondebosch, 7701, South Africa

\begin{abstract}
The southern African Later Stone Age sequence is widely considered to be well-dated based on radiocarbon dates from dozens of archaeological sites, and apparently shows more or less synchronous cultural shifts across an extensive area. Yet, closer examination reveals the inadequacy of many of the decades-old and uncalibrated individual site chronologies that underpin this regional chronology, making robust comparisons of the chronology of technological change across this region impossible. Here we present 26 new AMS radiocarbon dates and Bayesian modelled chronologies for two important archaeological cave sites in southernmost Africa, Nelson Bay Cave and Byneskranskop 1. The results provide more robust age estimates for these cultural and palaeoenvironmental sequences and revise interpretations of these sites in several instances. This project demonstrates the necessity of re-dating key sites, and the value of currently under-utilized methods, including calibration and Bayesian modelling, for southern African archaeology.
\end{abstract}




\subsection{Introduction}

The southern African Later Stone Age (LSA) is defined on the basis of stone artefact assemblages. Most LSA research is couched in terms of a well-defined succession of lithic industries, which seem to occur more or less simultaneously across the sub-continent (e.g. Lombard et al., 2012). This sequence was in large part first recognized and defined by changes in lithic technology observed in several key sites in southernmost Africa, including Nelson Bay Cave (J. Deacon, 1984), Boomplaas (H. Deacon, 1979), Kangkara (J. Deacon, 1984), Melkhoutboom (H. Deacon, 1976), and Byneskranskop 1 (Schweitzer and Wilson, 1982). Although the sequences of lithic changes are clear, none of these sites is dated comprehensively enough or with sufficient precision to evaluate whether technological changes appear simultaneously or diachronically across the region. Given the marked environmental gradients and the extensive area over which similar LSA industries are found, their apparent synchrony across the subcontinent warrants closer investigation and testing. Moreover, the valuable palaeoenvironmental records recovered from these sites (e.g. Avery, 1982; Faith, 2013; Klein, 1976; Scholtz, 1986; Sealy, 1996) can be of only limited use in comparison with global and regional climate and environmental records without precise chronologies with which to correlate them to one another and to regional climate shifts.

Table 1. Southern African lithic cultural sequence, with key characteristics and approximate age range, as summarized by Lombard et al. (2012).

\begin{tabular}{lllr}
\hline General category & Industry & Key typo/technological characteristics & \multicolumn{1}{c}{$\begin{array}{l}\text { Current dated } \\
\text { range [uncal] }\end{array}$} \\
\hline \hline $\begin{array}{l}\text { Late Holocene } \\
\text { assemblages }\end{array}$ & Ceramic LSA & Microliths, grindstones, ceramics & $<2 \mathrm{ka}$ \\
& Final LSA & Considerable variability, mostly informal & c. 100a - 4ka \\
\hline Holocene microlithic & Wilton & Microlithic, highly standardized & c. 4- 8ka \\
\hline $\begin{array}{l}\text { End Pleist./early Holocene } \\
\text { non-microlithic }\end{array}$ & Albany (Oakhurst) & $\begin{array}{l}\text { Flake-based, few microliths and formal } \\
\text { lithic tools }\end{array}$ & c. 7- 12ka \\
\hline $\begin{array}{l}\text { Terminal Pleistocene } \\
\text { microlithic }\end{array}$ & Robberg & $\begin{array}{l}\text { Systematic bladelet (<26 mm) production, } \\
\text { few formal tools }\end{array}$ & c. 12 - 18ka \\
\hline Early LSA & Early LSA (informal) & $\begin{array}{l}\text { Highly variable, features of LSA and MSA, } \\
\text { possibly mixed assemblages }\end{array}$ & c. 18- 40ka \\
\hline \hline
\end{tabular}

\subsection{Background}

The southern African LSA technological sequence is widely considered as well-characterized, with all varieties of toolmaking over the last c. 25 ka accommodated within the current schema (see Table 1; Lombard et al., 2012). This stands in contrast to the Middle Stone Age, which is currently the subject of several sustained, intensive research projects addressing fundamental questions about lithic production as well as subsistence behavior, palaeoenvironments and chronology, to better understand the pathways of later modern 
human evolution in southern Africa (e.g. Conard and Will, 2015; Henshilwood et al., 2001; 2014; Jacobs et al., 2008; Lombard et al., 2010; Mackay, 2011; Mackay et al., 2014; Marean, 2010; 2014; Stewart et al., 2012; Wadley, 2006; Will et al., 2014). By comparison, LSA technologies and behaviors are thought to be already well-understood. For instance, early LSA technologies have even been explicitly linked with historical populations of Kalahari San hunter-gatherers (e.g. D'Errico et al., 2012), as an indication of the perceived demographic and cultural continuity throughout this period.

There are, however, still major unanswered questions, especially the precise timing, mechanisms, and drivers of major technological transitions. The southern African LSA is unusual in beginning much later than comparable technological transitions in other parts of Africa and Europe. Yet, the earliest LSA assemblages observed in southern Africa are variously assigned to ages that differ as widely as 40 to 20 ka (D'Errico et al., 2012; Opperman and Heydenrych, 1990; Wadley, 1991), and the relationship of the unstandardized and poorly characterized "early LSA" assemblages to the better-defined Robberg, a "true" LSA industry, is not well understood. There are hints that the origins of the terminal Pleistocene microlithic Robberg technocomplex (commonly given as c. $18-12$ ka BP) lie in the mountainous grassland interior, but this is based on merely a handful of conventional radiocarbon dates (Vogel et al., 1986; Mitchell, 1996). Similarly, the transitions to the terminal Pleistocene non-microlithic Albany/Oakhurst industry, commonly given as $\mathrm{c}$. 12 ka BP, and subsequently to the Holocene microlithic Wilton industry at c. 8 ka BP, are also dated by just a few widely dispersed, conventional radiocarbon dates in each instance. Consequently, the age boundaries of these industries are defined only approximately across the region, and nuanced comparison of technological change between sites is impossible.

In part, the imprecision in our understanding of the timing of LSA cultural changes reflects the manner in which radiocarbon measurements have been applied by archaeologists in the region. Calibration is surprisingly frequently overlooked, a consequence perhaps of the lack of a reliable method for calibrating Southern Hemisphere dates over longer timespans during the early years of radiocarbon applications. Many archaeologists chose not to calibrate radiocarbon dates and made comparisons between sites on the basis of the uncalibrated dates. However, this results in sometimes very considerable offsets between local and global datasets, and complicates, for example, assessments of climate drivers. The SHCal13 curve now exists for the Southern Hemisphere over the entire radiocarbon timescale (Hogg et al., 2013), removing previous barriers to calibration.

Furthermore, Bayesian statistical techniques that incorporate prior knowledge and assumptions to better constrain the range of probable values are now routinely applied in archaeological chronology research, but have yet to be widely applied to the southern African Later Stone Age record. Clearly, the prior assumptions employed will greatly affect the resulting age estimates, and so must be chosen with care and justification (Pettitt and Zilhão, 2015; Buck and Meson, 2015), but generally Bayesian methods enable the 
construction of more statistically robust age models (Bronk Ramsey, 2009). Their application to both individual site chronologies and regional technological transitions will maximize the utility of the comparatively small radiocarbon dataset for the region.

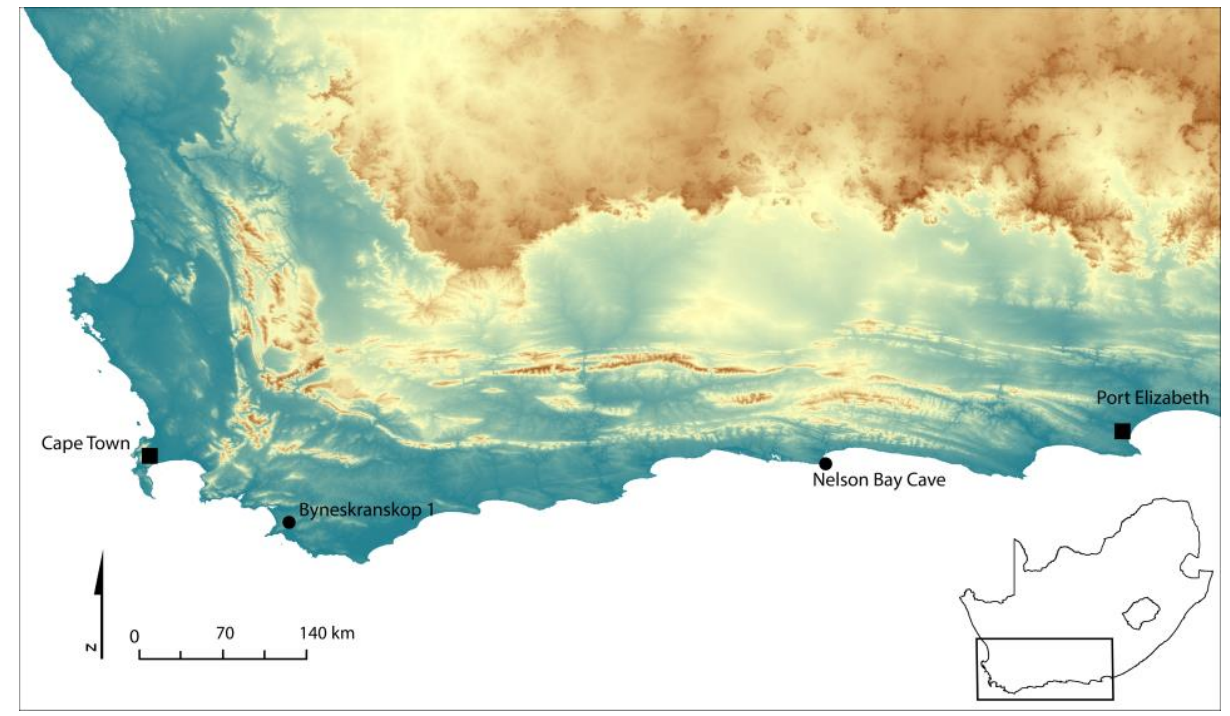

Figure 1.

Nowhere are these problems more apparent than at the sites of Nelson Bay Cave (NBC) and Byneskranskop 1 (BNK1) (see Figure 1). Both sites contain near-continuous LSA sequences with stone artefact assemblages characterized as Robberg through to the Post-Wilton, and the deposits at NBC extend into the Middle Stone Age. NBC, in particular, has been the focus of several foundational studies of the lifeways of LSA peoples in the region (e.g. Inskeep, 1987; Klein, 1972; Deacon 1984) and key in establishing the LSA technological sequence and its timing (Deacon, 1984). BNK1 is situated at the present boundary of the winter and yearround rainfall zones and consequently the palaeoenvironmental proxies contained in the site should be sensitive to past shifts in the regional weather systems. The site is thus a valuable palaeoenvironmental repository (Faith et al., 2013). However, both sites were excavated in the 1960s and/or 1970s, and the existing chronologies are decades old, predating the adoption of many of the methodological improvements in radiocarbon dating that are now standard. Most obviously, the dates typically have very large errors and some were measured on materials now considered unsuitable for radiocarbon analysis (see Tables 2 and 3). In addition, the materials, contexts and pretreatment methods for the radiocarbon analyses were not reported in detail (Deacon, 1984; Fairhall et al., 1976; Schweitzer and Wilson, 1982), making it difficult to evaluate the reliability of each date.

Here we present new accelerator mass spectrometry (AMS) radiocarbon dates and Bayesian modelled chronologies for NBC and BNK1, both to test and supplement the existing sets of dates for these sites, and to evaluate the coherence of the chronologies within the commonly accepted LSA chronological framework. 


\subsection{The sites}

\section{Nelson Bay Cave}

NBC is located a few meters above the modern-day seashore on the Robberg Peninsula near the town of Plettenberg Bay (Figure 1). The upper deposits, spanning the Holocene, consist of a series of shell middens and shell-rich occupations layers (J. Deacon, 1984). The underlying terminal Pleistocene levels are occupation deposits with no marine shell but good organic preservation. The levels re-dated here, spanning the mid-Holocene to approximately the Last Glacial Maximum (see Figure 2), were excavated in 1970/71 by Richard Klein (Klein 1972a, b) and described in detail in Janette Deacon's doctoral thesis (J. Deacon, 1984). Stratigraphic levels were identified on the basis of sedimentological changes, and the archaeological material stored according to stratigraphic level and square.

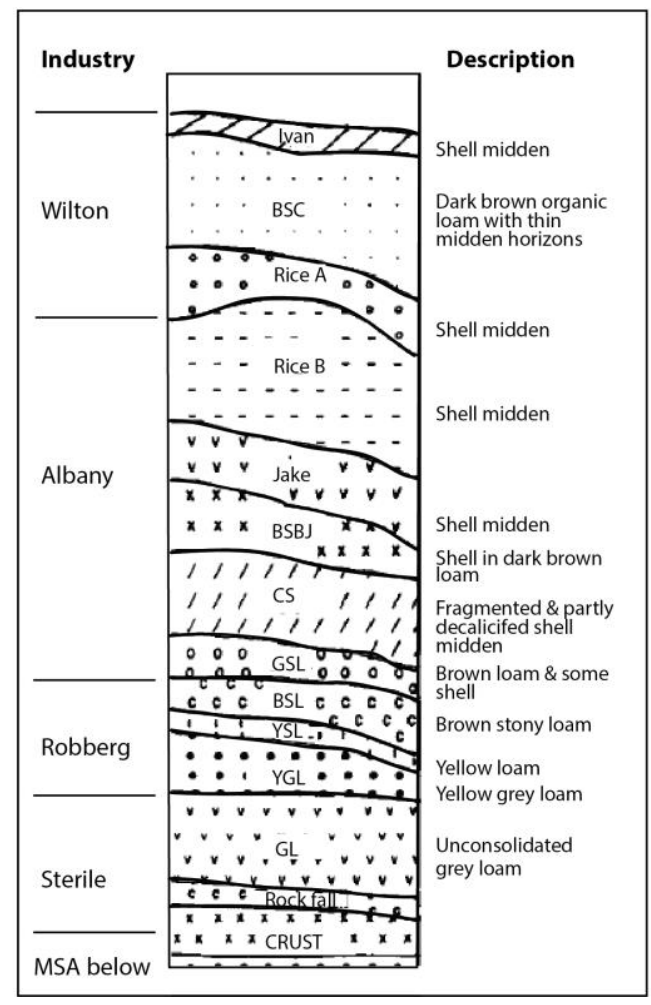

Figure 2.

The chronology for the mid- to early-Holocene and Late Pleistocene levels excavated by Klein was based on 24 conventional radiocarbon dates (Table 2), measured largely at the University of Washington laboratory and reported in Fairhall et al. (1976). Many of the dates have very broad errors, and in several instances the samples contained mixtures of marine and terrestrial derived carbon. The existing set of dates contains several inversions and some levels are constrained by only a single date. Despite the clear inadequacies of a number of the individual dates, and the inversions, the Nelson Bay Cave sequence is generally considered secure, reflected in the site's importance for local and regional 
archaeological narratives. Particular problems include lack of clarity as to the timings of the transitions between layers that have yielded stone artefact assemblages characterized as Robberg, Oakhurst and Wilton. Refining these boundaries was a focus of the present project. In addition, targeted sample selection and improved pretreatment protocols are expected to influence the age estimates of many levels, probably by extending the age of the older deposits.

Table 2. Existing conventional radiocarbon dates from Nelson Bay Cave (Deacon 1984) with sample material details (reported in Fairhall et al. (1976)). Dates are calibrated using OxCal, SHCal13 (Hogg et al., 2013), reported at $2 \sigma$ range. Dates on shell are calibrated using Marine13 (Reimer et al., 2013), with a local reservoir of $172 \pm 59$ years calculated from

\begin{tabular}{|c|c|c|c|c|c|c|c|}
\hline \multirow[t]{2}{*}{ Layer } & \multirow{2}{*}{$\begin{array}{l}\text { Cultural } \\
\text { unit }\end{array}$} & \multirow[t]{2}{*}{ ID no. } & \multirow{2}{*}{$\begin{array}{l}\text { Date } \\
\text { [uncal] }\end{array}$} & \multirow[t]{2}{*}{ \pm} & \multicolumn{2}{|c|}{ Date [calBP] } & \multirow[t]{2}{*}{ Material } \\
\hline & & & & & From & To & \\
\hline Ivan & Wilton & UW-217 & 4860 & 65 & 5235 & 4713 & Shell \\
\hline \multirow{4}{*}{ BSC } & Wilton & UW-216 & 5830 & 115 & 6878 & 6318 & Charcoal \\
\hline & & UW-186 & 6050 & 80 & 7156 & 6661 & $\begin{array}{l}\text { Charcoal rich soil, bone fragments } \\
\text { removed }\end{array}$ \\
\hline & & UW-176 & 6020 & 160 & 7245 & 6467 & $\begin{array}{l}\text { Charcoal fragments separated from } \\
\text { soil }\end{array}$ \\
\hline & & UW-187 & 5825 & 150 & 6950 & 6289 & Charcoal rich soil, no fragments \\
\hline \multirow[t]{2}{*}{ Rice A } & Wilton & UW-222 & 6070 & 125 & 7246 & 6568 & Charcoal fragments \\
\hline & & UW-179 & 9080 & 185 & 10156 & 9165 & Shell, Patella \\
\hline \multirow[t]{2}{*}{ Rice B } & Oakhurst & UW-181 & 8070 & 240 & 9475 & 8413 & $\begin{array}{l}\text { Small charcoal frags, shells and sand } \\
\text { mixed in }\end{array}$ \\
\hline & & UW-184 & 8570 & 170 & 9424 & 8533 & Shell, Patella \\
\hline Jake & Oakhurst & Pta-391 & 8990 & 80 & 10243 & 9771 & Charcoal \\
\hline \multirow[t]{2}{*}{ BSBJ } & Oakhurst & Q-1085 & 10256 & 210 & 12552 & 11256 & Ash with charcoal \\
\hline & & UW-178 & 10540 & 110 & 12671 & 12035 & $\begin{array}{l}\text { Dense, clay-like black material with no } \\
\text { clear charcoal }\end{array}$ \\
\hline \multirow[t]{3}{*}{ CS } & Oakhurst & Pta-392 & 10150 & 90 & 12015 & 11321 & Charcoal from hearth \\
\hline & & UW-164 & 10180 & 85 & 12045 & 11348 & $\begin{array}{l}\text { Charcoal frags in sediment mix of } \\
\text { shells, soil }\end{array}$ \\
\hline & & UW-162 & 11505 & 110 & 13490 & 13082 & $\begin{array}{l}\text { Charcoal frags in sediment mix of } \\
\text { shells, soil }\end{array}$ \\
\hline \multirow[t]{2}{*}{ GSL } & Oakhurst & UW-177 & 11950 & 150 & 14118 & 13445 & $\begin{array}{l}\text { Large fragments of charcoal in } \\
\text { sediment }\end{array}$ \\
\hline & & I-6515 & 11080 & 260 & 13450 & 12433 & $\begin{array}{l}\text { Large fragments of charcoal in } \\
\text { sediment }\end{array}$ \\
\hline BSL & Robberg & UW-218 & 10600 & 150 & 12728 & 12004 & Charcoal \\
\hline YSL & Robberg & I-6516 & 16700 & 240 & 20695 & 19527 & Charcoal \\
\hline \multirow[t]{2}{*}{ YGL } & Robberg & UW-175 & 18100 & 550 & 23190 & 20513 & $\begin{array}{l}\text { Finely divided charcoal in a mixture of } \\
\text { clay material }\end{array}$ \\
\hline & & GrN-5884 & 18660 & 110 & 22797 & 22258 & Ostrich eggshell fragments \\
\hline \multirow[t]{3}{*}{ MSA } & MSA & UW-224 & 17600 & 195 & 21783 & 20708 & Black earth \\
\hline & & UW-223 & 24120 & 660 & 29779 & 27125 & Black earth \\
\hline & & UW-290 & 22400 & 340 & 27348 & 25989 & Brown soil \\
\hline
\end{tabular}


Dewar et al., 2012 and Southon et al., 2002.

\section{Byneskranskop 1}

BNK1 is a cave located on the side of the Byneskranskop hill, presently about $7 \mathrm{~km}$ from the coastline, in the Uilkraals river valley (Figure 1). The site was excavated by Frank Schweitzer and a team from the South African Museum (now Iziko South African Museum) in 1974 and 1976 and contains a wealth of well-preserved organic material, including remains of large and micro-mammals, charcoal and shellfish. The poorly stratified deposits were originally divided into 64 stratigraphic units based on sedimentological features, and subsequently aggregated into 20 levels (Figure 3) (Schweitzer and Wilson, 1982). The deposits span the terminal Pleistocene to the late Holocene, with a complete lithic sequence from the Robberg to the ceramic LSA, and thus comparable to the NBC sequence. The existing chronology of the site (see Table 3 ) is based on 12 conventional radiocarbon dates produced in the 1970s that span the recent Late Holocene back to c. 12 ka BP. The dates were reported in minimal detail (Schweitzer and Wilson, 1982), with little information available about sample material, pretreatment protocols, or detailed stratigraphic information. There are several long gaps in this chronology but the relative paucity of dates makes it unclear whether they represent true occupational hiatuses, or result from changing intensity of occupation through the sequence. The aim of this redating project was thus principally to constrain the ages of the undated levels and to confirm the existing dates, as a foundation for comparisons with NBC and the regional technological sequence.

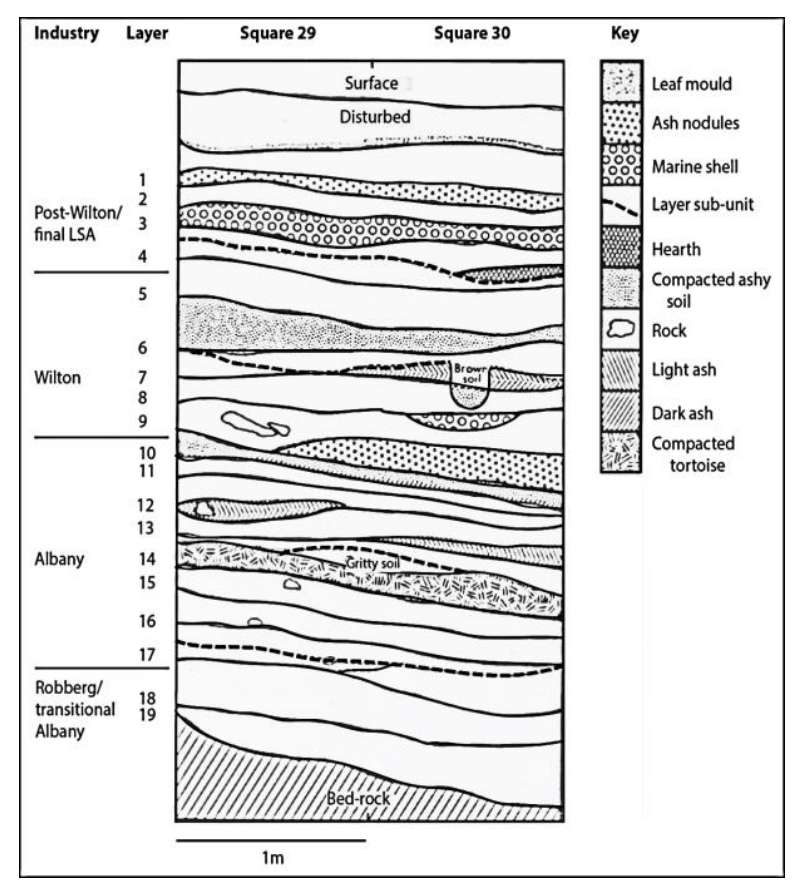

Figure 3. 
Table 3. Previously published radiocarbon dates from Byneskranskop 1 (materials unreported; Schweitzer and Wilson, 1982). Dates are calibrated using OxCal, SHCal13, reported at $2 \sigma$ range.

\begin{tabular}{llrrrrl}
\hline Stratum & Lab no. & Date & \pm & \multicolumn{3}{c}{ Calibrated date } \\
& & [uncal] & & From & \multicolumn{1}{c}{ To } & Unit \\
\hline Layer 1 & Pta-1864 & 255 & 50 & 443 & $\ldots$ & Post-Wilton \\
& Pta-1866 & 535 & 50 & 630 & 465 & Post-Wilton \\
& Pta-1865 & 1880 & 50 & 1897 & 1612 & Post-Wilton \\
& Pta-1631 & 3220 & 45 & 3556 & 3251 & Post-Wilton \\
Layer 2 & Pta-1569 & 3400 & 55 & 3818 & 3450 & Post-Wilton \\
Layer 5 & Pta-1571 & 3900 & 60 & 4434 & 4087 & Wilton \\
Layer 9 & Pta-1772 & 6100 & 140 & 7268 & 6567 & Wilton \\
& UW-409 & 6370 & 90 & 7428 & 7009 & Wilton \\
Layer 10 & Pta-1905 & 6540 & 55 & 7552 & 7279 & Oakhurst \\
Layer 12 & Pta-2347 & 7750 & 90 & 8725 & 8342 & Oakhurst \\
Layer 14 & Pta1587 & 9760 & 55 & 11245 & 10796 & Oakhurst \\
Layer 19 & I-7948 & 12730 & 185 & 15669 & 14236 & Robberg \\
\hline \hline
\end{tabular}

\subsection{Materials and methods}

\section{Materials}

Fourteen new dates were acquired for NBC from bovid long-bone shaft fragments and twelve new dates were acquired for BNK1 from tortoise carapace fragments. Both collections are accessioned at the Iziko South African Museum in Cape Town where they are stored in paper bags. No consolidants or chemicals were used on the bones for conservation.

\section{Pretreatment and measurement}

The Oxford Radiocarbon Accelerator Unit (ORAU) extraction method for bone collagen, with ultrafiltration, was used (Brock et al., 2010). Only samples with $>1 \%$ collagen yield and C:N ratios in the range 2.9-3.6 were passed for graphitization. Graphite was produced using the method of Bronk Ramsey and Hedges (1997) and dated on the ORAU HVEE AMS system (Bronk Ramsey et al., 2004). The greater sensitivity of AMS systems permits measurement of considerably smaller samples than required for conventional beta-counting measurements, and typically produces more accurate and precise dates.

\section{Calibration and Bayesian modelling}

The radiocarbon measurements were calibrated using the software OxCal (v. 4.2) (Bronk Ramsey, 1995; Bronk Ramsey, 2009), using the SHCal13 calibration curve for the Southern Hemisphere (Hogg et al., 2013) and the Marine13 curve, where the old conventional dates are based on shell (Reimer et al., 2013). The dates were also modelled according to Bayesian statistical principles in OxCal, using stratigraphic information from the Deacon (1984) and Schweitzer and Wilson (1982) monographs for NBC and BNK1 respectively. 


\subsection{Results and discussion}

\section{Nelson Bay Cave}

The radiocarbon measurements for NBC are presented in Table 4, together with the calibrated range (at $2 \sigma$ ) and $\delta^{13} \mathrm{C}$ values based on isotope ratio mass spectrometry measurements. The new dates for NBC are largely consistent with the old chronology (Table 2), although the new information modifies the existing interpretation of the technological sequence (Deacon, 1984) and the palaeoenvironmental reconstruction based on the faunal assemblage (Klein, 1972) in several instances (see modelled results in Figure 4).

Table 4. AMS dates on bone collagen (bovid long bone shaft fragments) from Klein's excavation at Nelson Bay Cave, with $\% \mathrm{C}$ and $\delta^{13} \mathrm{C}$. Dates are calibrated using the SHCal13 curve (Hogg et al., 2013), and reported to $2 \sigma$, rounded outwards to $5 \mathrm{yr}$.

\begin{tabular}{lllrrrrrrrrrr}
\hline Layer & Cultural & OxA & Date & \pm & \multicolumn{2}{c}{ Calib. date } & \multicolumn{2}{c}{ Collagen } & $\delta^{13}$ C & F14C & \pm & C:N \\
& Unit & number & [uncal] & \multicolumn{2}{c}{ from } & \multicolumn{1}{l}{ to } & Yield [\%] & [\%oPDB] & & & \\
\hline Ivan & Wilton & OxA-32448 & 4968 & 31 & 5730 & 5590 & 8.9 & -11.2 & 0.539 & 0.0021 & 3.4 \\
Ivan & Wilton & OxA-32449 & 4860 & 45 & 5655 & 5330 & 11.9 & -22.1 & 0.546 & 0.003 & 3.4 \\
Rice A & Wilton & OxA-32450 & 8281 & 38 & 9400 & 9030 & 8.9 & -11.6 & 0.357 & 0.0017 & 3.4 \\
Rice B & Oakhurst & OxA-32451 & 8550 & 37 & 9545 & 9460 & 6.7 & -10.2 & 0.345 & 0.0016 & 3.3 \\
Rice B & Oakhurst & OxA-32452 & 8447 & 39 & 9520 & 9305 & 6.8 & -11.7 & 0.349 & 0.0017 & 3.4 \\
Jake & Oakhurst & OxA-32453 & 9325 & 45 & 10590 & 10275 & 1.3 & -19.0 & 0.313 & 0.0017 & 3.4 \\
BSBJ & Oakhurst & OxA-32454 & 10155 & 45 & 11975 & 11405 & 4.3 & -12.2 & 0.283 & 0.0016 & 3.4 \\
CS & Oakhurst & OxA-32455 & 10340 & 50 & 12400 & 11825 & 1.7 & -19.7 & 0.276 & 0.0017 & 3.4 \\
GSL & Oakhurst & OxA-32456 & 12425 & 55 & 14810 & 14125 & 5.0 & -8.7 & 0.213 & 0.0014 & 3.4 \\
BSL & Robberg & OxA-32606 & 12155 & 55 & 14135 & 13775 & 3.8 & -10.3 & 0.22 & 0.0015 & 3.4 \\
BSL & Robberg & OxA-32457 & 10450 & 50 & 12515 & 12020 & 5.6 & -19.7 & 0.272 & 0.0017 & 3.4 \\
YSL & Robberg & OxA-32458 & 14715 & 65 & 18050 & 17645 & 6.1 & -13.8 & 0.16 & 0.0013 & 3.4 \\
YGL & Robberg & OxA-32607 & 18450 & 100 & 22485 & 21960 & 5.3 & -21.9 & 0.101 & 0.0013 & 3.4 \\
YGL & Robberg & OxA-32608 & 19110 & 110 & 23355 & 22615 & 1.3 & -14.3 & 0.093 & 0.0012 & 3.4 \\
\hline \hline
\end{tabular}




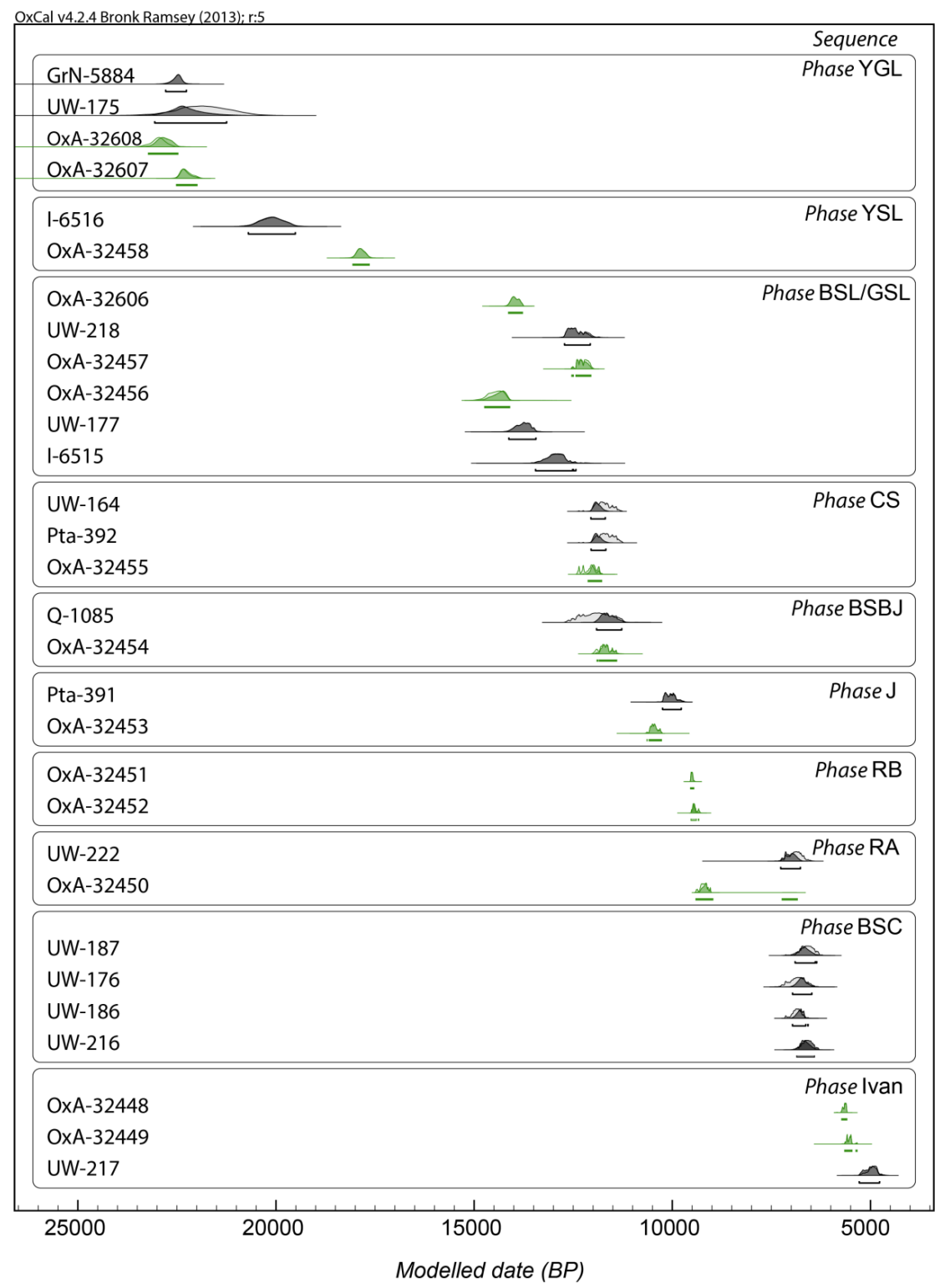

Figure 4

The age of the lowest LSA level, YGL, is extended by c. 500 years to $19110 \pm 110 \mathrm{BP}$, making it one of the oldest dated Robberg lithic assemblages in southern Africa, and the earliest assemblage in the southern Cape. The two earliest dated Robberg assemblages are located in the Lesotho highlands, at Melikane (Pta-1407, $20200 \pm$ 150) and Sehonghong (Pta-6281, $19400 \pm 200$ ) (Vogel et al., 1986; Mitchell, 1996). The new dates for layer YGL hint that the presence of the earliest dates (i.e. the apparent origin of) the Robberg in the interior, grassland region of the subcontinent may simply reflect the frequency of well-dated assemblages there, and the pattern may change as other sites across the region are reliably dated. Alternatively, if the Robberg does first appear in the Lesotho highlands, then the technology spread even faster across the sub-continent than previously realized. Thus, the apparent contemporaneity of the Robberg in these widely dispersed sites has implications 
for models of the origin and spread of terminal Pleistocene microlithic bladelet technologies across southern Africa.

The new date for layer YSL at $14715 \pm 65 \mathrm{BP}$ is c. $2 \mathrm{ka}$ younger than the previous date for this level. This date confirms the discontinuity between YSL and the overlying levels, but indicates that any hiatus was briefer than previously realized, and that the site was possibly occupied more continuously during the terminal Pleistocene. The new date also affects interpretations of terminal Pleistocene megafaunal extinctions in southern Africa: the last appearance of an extinct giant Megalotragus species occurs in this level (Klein, 1972), and so the species may have persisted for longer than the previous date for this level suggests. A direct date for this specimen would help clarify the timing of this extinction event.

The new dates for layers GSL (Oakhurst) and BSL (Robberg) were undertaken to try to clarify the dating inversion in these levels, under the assumption that one or more of the existing conventional dates was erroneous, and to better constrain the age of the Robberg/Oakhurst transition at this site. However, three new dates for these levels confirm and extend the inversion, indicating that the stratigraphy in these levels is inverted or mixed. Although the excavation report makes no mention of any mixing, Mitchell's (1988) subsequent assessment of the lithic assemblage suggested that the material from both levels be considered transitional as it reflects a combination of features. The new dates instead indicate that the assemblages may be a mix of Robberg and Oakhurst material. This interpretation, however, conflicts with Klein's (1972) observations of a major turnover in the faunal assemblage between BSL and GSL, which he dated at c. 12000 BP and suggested reflected the onset of the Holocene. If BSL and GSL are mixed, then the faunal assemblages should not differ so markedly between the two levels. The evidence for mixing of the stratigraphy also confounds interpretations of the final appearance of the extinct giant buffalo, Pelorovis sp., which occurs in GSL.

New dates for layers Rice B (Oakhurst) and Rice A (Wilton) were undertaken to better constrain the age of the transition between the Oakhurst and Wilton. Previously, Deacon (1984) suggested that the base of Rice A likely dated to c. 7 ka BP, disregarding a date of 9 $080 \pm 185 \mathrm{BP}$ on marine shell. The underlying Rice B was dated to c. $8.5 \mathrm{ka}$ BP, more than 1000 years earlier, providing a very uncertain estimate of the timing of the transition. A new radiocarbon date for Rice A ( $8281 \pm 38 \mathrm{BP}$ ) now confirms that the Wilton begins relatively early at this site (at least 9400 - 9032 cal BP). In addition, two new dates for layer Rice B, constrain the age of this layer to c. 9500 cal BP, suggesting that the transition between the Oakhurst and Wilton occurred relatively rapidly at NBC.

Figure 5 shows modelled Date results for two Sequence models produced in OxCal: the upper model includes only the previously published dates, while the lower model incorporates the new AMS dates. Also shown are the modelled values at the $2 \sigma$ range. In both instances, the model would not run initially due to the inversion in layers BSL and GSL so these two levels have been combined, assuming that the stratigraphy in these levels was 
misunderstood. Further, not all the previously published dates reported in Table 3 are included in these models as several were identified as outliers: UW-162 from CS, UW-178 from BSBJ, UW-181 and UW-184 from Rice B and UW-179 from Rice A were excluded, according to the indice method in OxCal (Bronk Ramsey, 2009). In general, the additional dates better constrain the modelled age estimates for the levels, even where the new dates are very different from the old dates (e.g. level YSL). The improved estimates reflect the improved errors of the AMS dates and the effect of additional ages in the model.

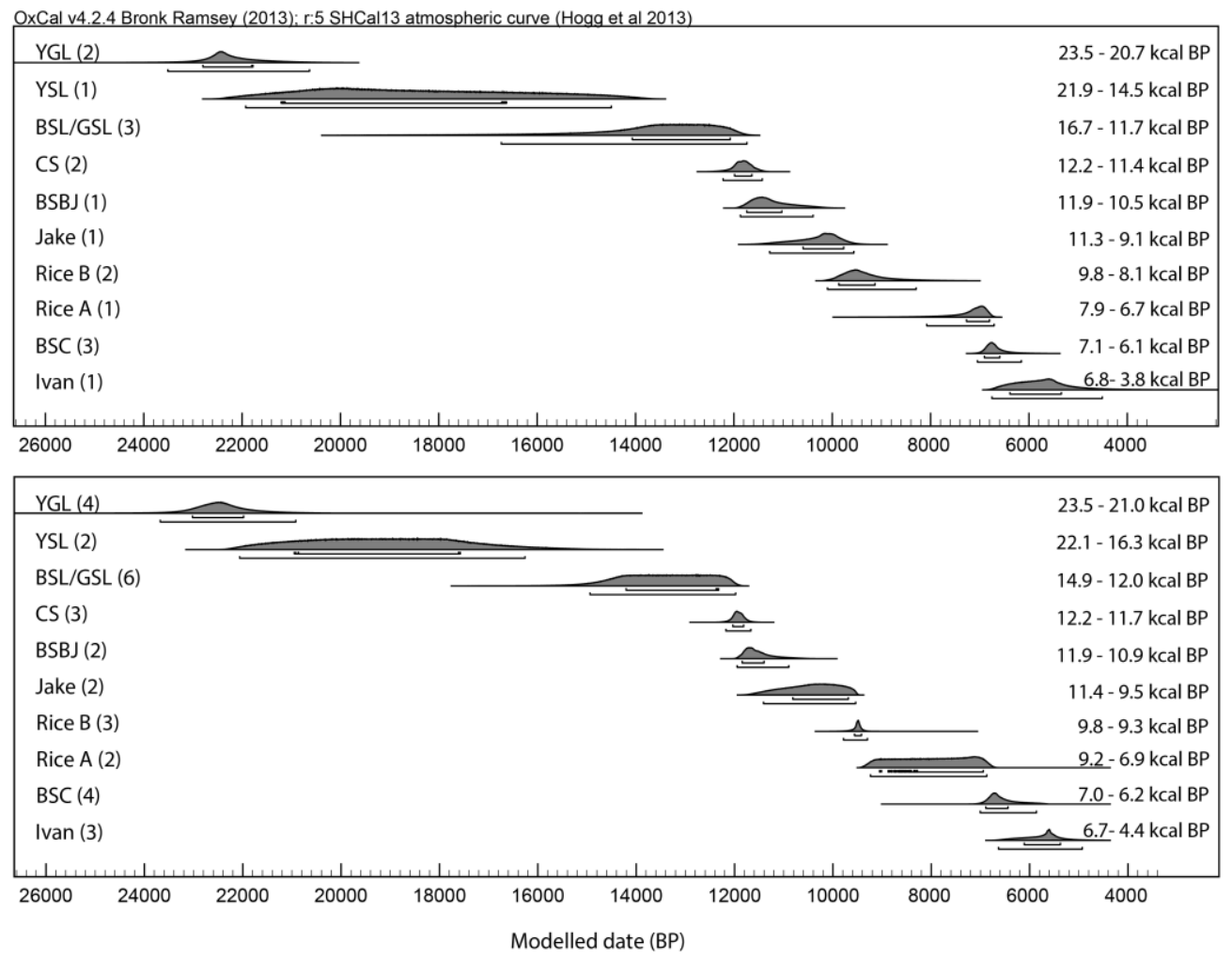

Figure 5

The modelled Date ranges for each level have some important implications for the timing of technological change as interpreted by Deacon (1984). Most notably, according to the original chronology, the occupation sequence at NBC witnessed an apparent hiatus of approximately 2000 years between the Oakhurst (Rice B) and Wilton (Rice A), and although Deacon observed continuities between the assemblages in these levels, she also noted that the hiatus served to accentuate the differences in these assemblages. Her reasoning suggests that the division of Rice $A$ and Rice $B$ assemblages into separate industries may have been at least partly justified by the temporal framework with which she was working, now known to be continuous over that period. Indeed, the updated chronology instead shows a rapid transition between the two levels. In addition, Deacon's interpretation of technological change from the Robberg to the Albany between levels GSL and BSL is challenged by the new dates for these levels which show that the stratigraphy between these levels was mixed. Consequently, the earliest securely dated Oakhurst assemblage at NBC comes from level CS, with a modelled age of 12174 - 11669 cal BP at the $2 \sigma$ range. 


\section{Byneskranskop 1}

The AMS radiocarbon measurements from BNK1 are presented in Table 5, together with the calibrated range (at $2 \sigma$ ) and $\delta^{13} C$ values. Dates OxA-32675 and OxA-32676 are repeats of the same sample, undertaken for quality assurance purposes. The \% collagen yield for OxA32684 was below $1 \%$, but the C:N ratio is within the range for well-preserved collagen and the date is considered secure. Layers 10,13 and 14 were originally also targeted for dating, but unfortunately samples from these levels did not yield sufficient collagen.

Table 5. AMS dates on bone collagen (tortoise carapace fragments) from Byneskranskop 1, with $\% C$ and $\delta^{13} C$. Dates are calibrated using the SHCal13 curve (Hogg et al., 2013), and reported to $2 \sigma$, rounded outwards to $5 \mathrm{yr}$.

\begin{tabular}{|c|c|c|c|c|c|c|c|c|c|c|c|}
\hline \multirow[t]{2}{*}{ Level } & \multirow{2}{*}{$\begin{array}{l}\text { Cultural } \\
\text { Unit }\end{array}$} & \multirow{2}{*}{$\begin{array}{l}\text { OxA } \\
\text { number }\end{array}$} & \multirow{2}{*}{$\begin{array}{l}\text { Date } \\
\text { [uncal] }\end{array}$} & \multirow[t]{2}{*}{ \pm} & \multicolumn{2}{|c|}{ Calib. date } & \multirow{2}{*}{$\begin{array}{l}\text { Collagen } \\
\text { Yield [\%] }\end{array}$} & \multirow{2}{*}{$\begin{array}{l}\delta^{13} \mathrm{C} \\
{[\% \circ \mathrm{PDB}]}\end{array}$} & \multirow[t]{2}{*}{ F14C } & \multirow[t]{2}{*}{ \pm} & \multirow[t]{2}{*}{$\mathrm{C}: \mathrm{N}$} \\
\hline & & & & & from & to & & & & & \\
\hline Level 1 & Post-Wilton & OxA-32675 & 1891 & 27 & 1870 & 1715 & 7.5 & -22.4 & 0.79 & 0.0026 & 3.4 \\
\hline Level 1 & Post-Wilton & OxA-32676 & 1891 & 28 & 1870 & 1715 & 8.2 & -22.3 & 0.79 & 0.0027 & 3.4 \\
\hline Level 4 & Wilton & OxA-32677 & 3599 & 28 & 3970 & 3720 & 6.9 & -22.4 & 0.639 & 0.0022 & 3.3 \\
\hline Level 5 & Wilton & OxA-32678 & 5428 & 33 & 6290 & 6015 & 6.6 & -21.8 & 0.509 & 0.0021 & 3.4 \\
\hline Level 6 & Wilton & OxA-32679 & 5684 & 32 & 6495 & 6315 & 9.3 & -22.7 & 0.493 & 0.002 & 3.3 \\
\hline Level 7 & Wilton & OxA-32680 & 5263 & 33 & 6180 & 5905 & 6.1 & -22.3 & 0.519 & 0.0021 & 3.3 \\
\hline Level 8 & Wilton & OxA-32681 & 5589 & 34 & 6410 & 6285 & 7.3 & -23.4 & 0.499 & 0.0021 & 3.3 \\
\hline Level 9 & Wilton & OxA-32682 & 6048 & 33 & 6945 & 6740 & 8.4 & -22.2 & 0.471 & 0.002 & 3.3 \\
\hline Level 11 & Transitional & OxA-32683 & 5872 & 33 & 6740 & 6505 & 3.7 & -21.5 & 0.481 & 0.002 & 3.3 \\
\hline Level 15 & Oakhurst & OxA-32684 & 10015 & 45 & 11695 & 11245 & 0.6 & -24.1 & 0.287 & 0.0017 & 3.3 \\
\hline Level 17 & Oakhurst & OxA-32685 & 12250 & 55 & 14320 & 13855 & 1.6 & -24.0 & 0.218 & 0.0015 & 3.4 \\
\hline Level 19 & Robberg & OxA-32686 & 13565 & 60 & 16535 & 16060 & 1.1 & -23.3 & 0.185 & 0.0014 & 3.3 \\
\hline Level 19 & Robberg & OxA-32687 & 13945 & 65 & 17105 & 16550 & 3.7 & -23.6 & 0.176 & 0.0014 & 3.4 \\
\hline
\end{tabular}


Schweitzer and Wilson (1982: 21) describe the stratigraphy generally as "poor", and note the possibility that some levels may have been miscategorized. The general coherence of the stratigraphy is confirmed with the new set of AMS dates (see Figure 6), although several inversions in the dates may indicate some mixing. Bayesian models can identify incongruities in the age sequences: in particular, the new ages for Layer 6 (OxA-32679) and Layer 11 (OxA-32683) are not accepted in the model and are highlighted as outliers according to the indice method (Bronk Ramsey, 2009). Layer 11 is described in the site report as an "in-fill", and Schweitzer and Wilson (1982) assign the lithic assemblage in levels 10-12 to a separate phase (phase 2/3), transitional between the Oakhurst (phase 2) and Wilton (phase 3 ), based on tool types and raw material patterning. Thus, the actual dates for these levels may reflect mixing in this part of the sequence. Unfortunately, given that these levels span the change from the Oakhurst to Wilton assemblages, the dating uncertainties undermine the possibility of studying this transition in detail at BNK1.

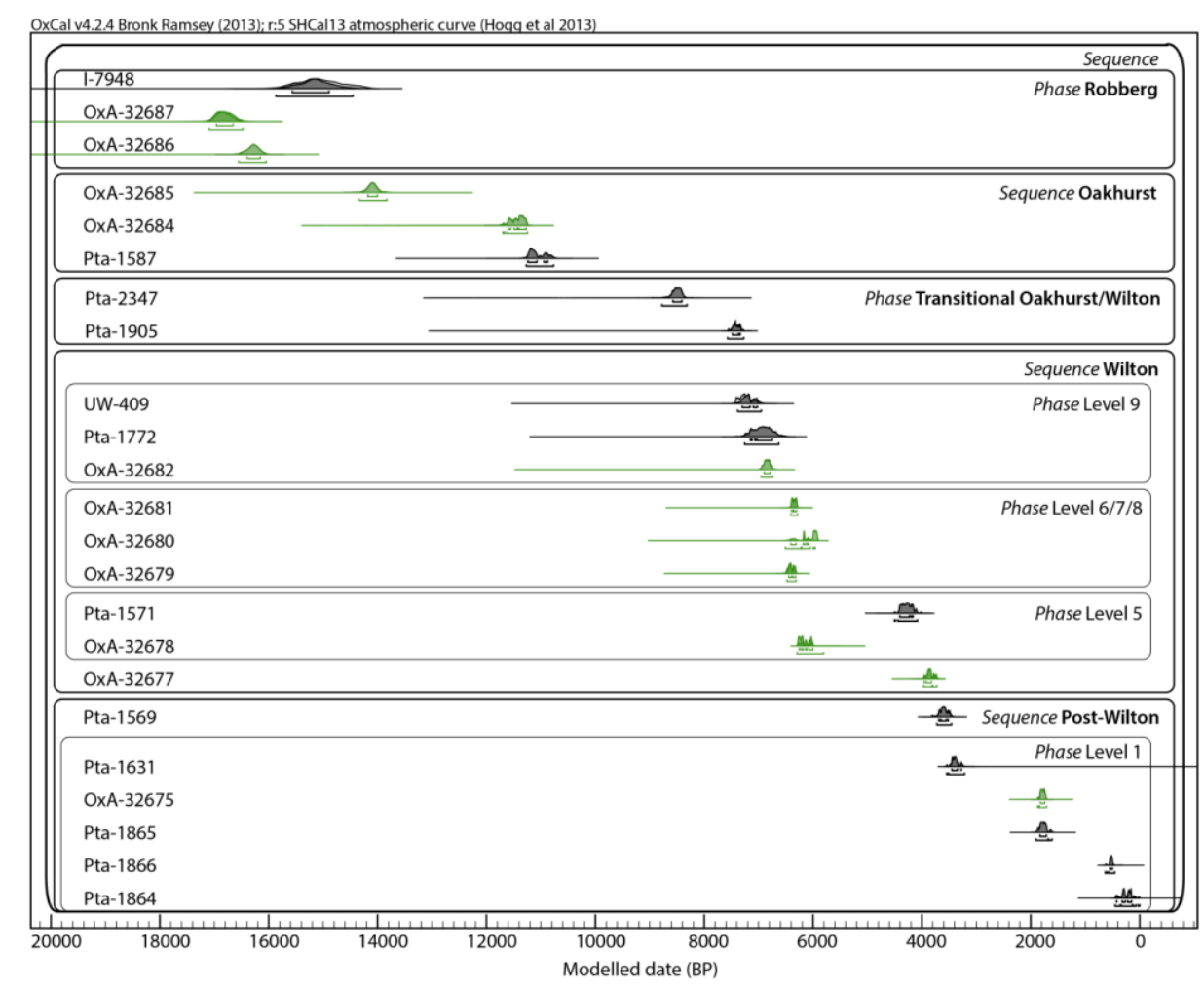

Figure 6

The inversion between Layer 6 and Layer 7 and 8 may be explained by the following description in the site report: "In places it was difficult to determine the base of layer 6, but on the whole layer 7 was less compacted and less ashy than layer 6[...]". The comparatively tight clustering of the three dates from Layers 6,7 and 8 , is taken to indicate rapid deposition over these levels, and they are modelled as reflecting a single phase.

Two new dates for the lowest level, Layer 19, attributed to the Robberg or a transitional Robberg/Oakhurst assemblage, extend the age range of the site by more than 1000 years, back to 17105 - 16555 calBP. The age of the first Oakhurst assemblage in Layer 17 is dated 
to $14320-13860$ calBP. This is the earliest AMS radiocarbon date for an Oakhurst assemblage and is the fourth earliest radiocarbon date for Oakhurst material, after the sites of Heuningneskrans (Vogel and Marais, 1971) and Bushman Rock Shelter (Vogel, 1986) in the savanna biome, and Kangkara in the southern Cape (Deacon, 1984). The calibrated range for level 17 at BNK1 is about two thousand years before the age commonly cited for the start of the Oakhurst at c. 12 ka BP (e.g. Lombard et al., 2012). This discrepancy highlights the importance of considering the calibrated age range, a surprisingly frequently overlooked consideration in discussions of technological change in southern Africa, and the value of more precise and accurate radiocarbon dating methods.

\subsection{Conclusions}

The updated modelled chronologies for both BNK1 and NBC provide more robust age estimates for the technological and palaeoenvironmental records contained in these sites. This study emphasizes the necessity of re-examining and redating important sites that were excavated decades ago, even where some of the recorded stratigraphic information has been lost. Principally, these results demonstrate that the onset of the major technological shifts in southern Africa occurred earlier than has previously been recognized. Comparing the timing of cultural and environmental shifts at different sites across the region is at present possible only in a very coarse framework. Assessing possible processes of innovation or diffusion is presently beyond our capabilities based on the small number of dates and to some degree to inadequate standards of reporting for radiocarbon data in the discipline (see Bayliss, 2015). Obtaining much denser suites of precise radiocarbon dates, coupled with routine application of calibration and statistical modelling at the local and regional scales, promises to maximize the utility of radiocarbon data for archaeological enquiries. Regardless of whether one chooses the approach taken here, considering technological change in terms of shifts between cultural categories such as 'Robberg' and 'Oakhurst/Albany', or prefers attribute-based analyses of lithic assemblages, chronological research such as this is necessary to facilitate more detailed and fruitful explorations of the southern African technological and palaeoenvironmental sequence.

\section{Acknowledgments}

Permissions for export and sampling were obtained from the curator of the archaeological collections at Iziko Museum and Heritage Western Cape (case number 15021902AS0219E). Thanks are due to W Black, W Seconna and L Hutten for help accessing the collections at Iziko and VJ Hare, R Staff, M Dee and M Wencel for help with OxCal. Research costs were supported in part by the South African Research Chairs Initiative of the Department of Science and Technology and the National Research Foundation of South Africa. The analyses were funded by the NERC Radiocarbon Facility (Archaeology), grant number NF/2015/1/11. 


\section{References}

Avery D. 1982. Micromammals as palaeoenvironmental indicators and an interpretation of the late Quaternary in the southern Cape Province, South Africa. Annals of the South African Museum 85:183-377.

Brock F, Higham TFG, Ditchfield P, Bronk Ramsey C. 2010. Current pre-treatment methods for AMS radiocarbon dating at the oxford radiocarbon accelerator unit (ORAU). Radiocarbon 52:103-112.

Bronk Ramsey C. 1995. Radiocarbon calibration and analysis of stratigraphy: the OxCal program. Radiocarbon 37:425-430.

Bronk Ramsey C. 2009a. Bayesian analysis of radiocarbon dates. Radiocarbon 51:337-360.

Bronk Ramsey C. 2009b. Dealing with outliers and offsets in radiocarbon dating. Radiocarbon 51(3):1023-45.

Bronk Ramsey C, Higham TFG, and Leach P. 2004. Towards high-precision AMS: Progress and limitations. Radiocarbon 46:17-24.

Conard NJ, Will M. 2015. Examining the Causes and Consequences of Short-Term Behavioral Change during the Middle Stone Age at Sibudu, South Africa. PloS One 10(6):e0130001.

Deacon HJ. 1976. Where hunters gathered: a study of Holocene Stone Age people in the Eastern Cape (Monograph Series No. 1). Claremont: South African Archaeological Society.

Deacon HJ. 1979. Excavations at Boomplaas cave: a sequence through the upper Pleistocene and Holocene in South Africa. World Archaeology 10:241-257.

Deacon J. 1984. The Later Stone Age of Southernmost Africa (Vol. 213). Oxford: British Archaeological Reports.

D’Errico F, Backwell L, Villa P, Degano I, Lucejko JJ, Bamford MK, Higham TFG, Beaumont P. 2012. Early evidence of San material culture represented by organic artifacts from Border Cave, South Africa. Proceedings of the National Academy of Sciences of the United States of America 109:13214-13219.

Dewar G, Reimer PJ, Sealy JC, Woodborne S. 2012. Late-Holocene marine radiocarbon reservoir correction ( R) for the west coast of South Africa. The Holocene 22(12):1481-1489.

Fairhall A, Young A, and Erickson J. 1976. University of Washington Dates IV. Radiocarbon 18:221-239.

Faith JT. 2013. Ungulate diversity and precipitation history since the Last Glacial Maximum in the Western Cape, South Africa. Quaternary Science Reviews 68:191-199. 
Henshilwood CS, Sealy JC, Yates R, Cruz-Uribe K, Goldberg P, Grine FE, Poggenpoel C, van Niekerk KL, Watts I. 2001. Blombos Cave, southern Cape, South Africa: preliminary report on the 1992 - 1999 excavations of the Middle Stone Age levels. Journal of Archaeological Science 28:421-448.

Henshilwood CS, van Niekerk KL, Wurz S, Delagnes A, Armitage SJ, Rifkin RF, Douze K, Keene P, Haaland MM, Reynard J, Discamps E, Mienies SS. 2014. Klipdrift Shelter, southern Cape, South Africa: preliminary report on the Howiesons Poort layers. Journal of Archaeological Science 45:284-303.

Hogg AG, Hua Q, Blackwell PG, Niu M, Buck CE, Guilderson TP, Heaton TJ, Palmer JG, Reimer PJ, Reimer RW, Turney CSM, Zimmerman SRH. 2013. SHCal13 Southern Hemisphere Calibration, 0-50,000 Years cal BP. Radiocarbon 55(4):1889-1903.

Jacobs Z, Roberts RG, Galbraith RF, Deacon HJ, Grün R, Mackay A, Mitchell PJ, Vogelsang R, Wadley L. 2008. Ages for the Middle Stone Age of southern Africa: implications for human behavior and dispersal. Science 322(5902):733-5.

Klein RG. 1972a. Preliminary report on the July through September 1970 excavations at Nelson Bay Cave, Plettenberg Bay (Cape Province, South Africa). Palaeoecology of Africa 6: 177-208.

Klein RG. 1972b. The Late Quaternary mammalian fauna of Nelson Bay Cave (Cape Province, South Africa): its implications for megafaunal extinctions and environmental and cultural change. Quaternary Research 2:135-42.

Klein RG. 1976. The mammalian fauna of the Klasies River Mouth sites, Southern Cape Province, South Africa. The South African Archaeological Bulletin 31:75-98.

Lombard M, Wadley L, Jacobs Z, Mohapi M, Roberts RG. 2010. Still Bay and serrated points from Umhlatuzana Rock Shelter, Kwazulu-Natal, South Africa. Journal of Archaeological Science 37(7):1773-1784.

Lombard M, Wadley L, Deacon J, Wurz S, Parsons I, Mohapi M, Swart J, Mitchell P. 2012. South African and Lesotho Stone Age sequence updated (I). South African Archaeological Bulletin 67:123-144.

Mackay A. 2011. Nature and significance of the Howiesons Poort to post-Howiesons Poort transition at Klein Kliphuis rockshelter, South Africa. Journal of Archaeological Science 38(7):1430-1440.

Mackay A, Sumner A, Jacobs Z, Marwick B, Bluff K, Shaw M. 2014. Putslaagte 1 (PL1), the Doring River, and the later Middle Stone Age in southern Africa's Winter Rainfall Zone. Quaternary International 350:43-58. 
Marean CW. 2010. Pinnacle point cave 13B (Western Cape Province, South Africa) in context: The cape floral kingdom, shellfish, and modern human origins. Journal of Human Evolution 59:425-443.

Marean CW. 2014. The origins and significance of coastal resource use in Africa and Western Eurasia. Journal of Human Evolution 77:17-40.

Mitchell P. 1988. The late Pleistocene early microlithic assemblages of southern Africa. World Archaeology 20(1):27-39.

Mitchell P. 1996. The Late Quaternary of the Lesotho Highlands, southern Africa. Quaternary International 33:35-43.

Mitchell P, Parkington JE, Wadley L. 1998. A Tale From Three Regions: the Archaeology of the Pleistocene/Holocene Transition in the Western Cape, the Caledon Valley and the Lesotho Highlands, Southern Africa. Quaternary International 49-50(97):105-115.

Opperman H, Heydenrych B. 1990. A 22000 year-old Middle Stone Age camp site with plant food remains from the north-eastern Cape. The South African Archaeological Bulletin 45(152):93-99.

Reimer PJ, Bard E, Bayliss A, Beck JW, Blackwell PG, Ramsey CB, Buck CE, Cheng H, Edwards RL, Friedrich $M$, Grootes PM, Guilderson TP, Haflidison $H$, Hajdas I, Hatté $C$, Heaton $T$, Hoffmann DL, Hogg A, Hughen KA, Kaiser K, Kromer B, Manning SW, Niu M, Reimer R, Richards DA, Scott EM, Southon JR, Staff RA, Turney C, Plicht J. 2013. IntCal13 and Marine13 radiocarbon age calibration curves 0-50,000 years cal BP. Radiocarbon 55:1869-1887.

Scholtz A. 1986. Palynological and Palaeobotanical Studies in the Southern Cape. MA thesis, University of Stellenbosch.

Schweitzer FR, Wilson M. 1982. Byneskranskop 1: A Late Quaternary living site in the southern Cape Province. The Annals of the South African Museum 88:1-102.

Sealy JC. 1996. Seasonality of rainfall around the Last Glacial Maximum as reconstructed from carbon isotope analyses of animal bones from Nelson Bay Cave. South African Journal of Science 92:441-444.

Southon JR, Kashgarian M, Fontugne M, Metivier B, Yim W. 2002. Marine reservoir corrections for the Indian Ocean and Southeast Asia. Radiocarbon 44:167-180.

Stewart BA, Dewar GI, Morley MW, Inglis RH, Wheeler M, Jacobs Z, Roberts RG. 2012. Afromontane foragers of the Late Pleistocene: Site formation, chronology and occupational pulsing at Melikane Rockshelter, Lesotho. Quaternary International 270:40-60.

Vogel JC, Marais M. 1971. Pretoria radiocarbon dates I. Radiocarbon 13:378-394. 
Vogel JC, Fuls A, Visser E. 1986. Pretoria radiocarbon dates III. Radiocarbon 28:1133-1172.

Wadley L. 1991. Rose Cottage Cave: Background and a preliminary report on the recent excavations. The South African Archaeological Bulletin 46(154):125-130.

Wadley L. 2006. Partners in grime: results of multi-disciplinary archaeology at Sibudu Cave. Southern African Humanities 18:315-341.

Will M, Kandel A, Conard NJ. 2014. Coastal adaptations and settlement systems on the Cape and Horn of Africa during the Middle Stone Age. In: Conard NJ, Delagnes A, editors. Settlement dynamics of the Middle Paleolithic and Middle Stone Age. Tuebingen: Kerns Verlag. Vol 4, p 61-89. 